\title{
Diyabetik ayak: Patogenez, klinik tablolar ve tedavileri, eş zamanlı hastalıklar
}

\section{Diabetic foot: pathogenesis, clinical forms and their management, comorbidities}

\author{
Mehmet Oğuz Durakbaşa
}

Haydarpaşa Numune Eğitim ve Araştırma Hastanesi, Ortopedi ve Travmatoloji Kliniği, İstanbul

\begin{abstract}
Diyabetik polinöropati ile başlayan, diyabetik ayak ülseri, Charcot osteoartropatisi (CNO) gibi klinik tablolarla karşımıza çıkan diyabetik ayak periferik vasküler hastalık (PVH) ve infeksiyonla komplike olabilir ve ampütasyon gerekebilir. Son dönem böbrek yetersizliği ve kardiovasküler hastalık gibi eşzamanlı hastalıklar ampütasyon ve ölüm oranı riskini daha da arttıran etmenlerdir.

Her ne şekilde karşımıza çıkarsa çıksın, diyabetik ayak tedavi edilirken ana sorunun hastanın bozulmuş glisemik kontrolü ve metabolizması olduğu unutulmamalıdır. Metabolik düzen sağlanmadan ortopedik tedavide başarı olası değildir. Ortopedik tedavide yapılabilecekler arasında, hasta ve yakınlarının diyabetik ayak eğitimi ve korunma önlemleri; ülser için pansuman terliği, özel yapım ayakkabılar, tam temaslı alçı ve debridman; CNO için tam temasIı alçı ve cerrahi tedavi; infeksiyon için antibiyoterapi, acil cerrahi girişim ve ampütasyon; $\mathrm{PVH}$ için revaskülarizasyon girişimleri sayılabilir.

Günümüzde diyabetik ayağın moleküler düzeydeki patogenezinde şeker metabolizmasının bozulmasına bağlı "kontrolsüz inflamasyon" üzerinde durulmakta ve yeni ilaç tedavileri üzerinde çalışılmaktadır. Morbidite ve ölüm oranını arttıran diyabetin bu komplikasyonunun tedavisinde bu yeni ilaçlar umut vaat eden bir ufuk açabilir.
\end{abstract}

Anahtar sözcükler: diyabetli ayak; patogenez; nöropati; ülser; Charcot ayağı; ampütasyon; eşzamanlı hastalık; ölüm oranı
Diabetic foot which begins with diabetic polyneuropathy and appears as clinical forms like diabetic foot ulcer and Charcot osteoarthropathy (CNO) can be complicated by peripheric vascular disease (PVD) or infection and amputation can pursue. The factors that multiply amputation and mortality risks are the comorbidities like end-stage renal failure and cardiovascular disease.

While treating diabetic foot, it should not be forgotten that the main problem is the patient's impaired glycemic control and metabolism. It is impossible to be successful in orthopaedic management without achieving metabolic homeostasis. Orthopaedic treatment options are educating the patients and their relatives about diabetic foot and about the precautions to prevent it; healing sandal, special footwear, total contact cast and debridement for diabetic foot ulcers; total contact cast and surgical treatment for CNO; antibiotic treatment, emergency surgery and amputation for diabetic foot infection; revascularization procedures for PVD.

Currently, "uncontrolled inflammation" due to impairment of glucose metabolism is emphasized as the pathogenesis of diabetic foot on molecular basis and research is done for new drugs. These new drugs may create new horizons for the treatment of this complication of diabetes that may be promising.

Key words: foot with diabetes; pathogenesis; neuropathy; ulcer; Charcot foot; amputation; comorbidity; mortality

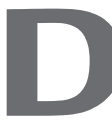
iyabetik ayak, kan şekeri düzeni bozulmuş, metabolizması alt üst olmuş diyabet hastasında bir göstergedir. Sıklıkla periferik nöropati (PN), ayak ülseri, Charcot nöropatik osteoartropatisi (CNO) şeklinde karşımıza çıkan diyabetik ayak olgularının hepsinde ana sorun metabolizma bozukluğudur ve diyabet hastalığı ile ilgili dahili sorunlar düzeltilmedikçe diyabetik ayak tedavisinde başarı olası değildir.
Bu nedenle, diyabetik ayağın "diyabetli ayak" olarak isimlendirilmesi daha uygun olabilir.

Diyabet hastasında "diyabetik ayak" komplikasyonu çıkmaması için hastaların eğitilmesi, ayak bakımını nasıl yapacağının, ne tip çorap ve ayakkabı giyeceğinin öğretilmesi gerekmektedir. Hastalar ana hastalığıyla ilgili bilgilendirilir ve diyabetin kontrolünün komplikasyonları önlemede ön şart olduğu yönünde

- İletişim adresi: Uzm. Dr. Mehmet Oğuz Durakbaşa, SOYAK Gökyüzü Konutları, C Blok, D:45, Barbaros Mahallesi, Karayolları Site Sokak, no:5, 34662 Üsküdar, İstanbul Tel: 0532 - 7652442 e-posta: odurakbasa@yahoo.com

- Geliș tarihi: 16 Eylül 2013 Kabul tarihi: 10 Kasım 2013 
bilinçlendirilirse "diyabetik ayak" komplikasyonu da ciddi oranda azaltılabilir.

Bu derlemede sırasıyla, "diyabetik ayak" ile ilgili demografik bilgiler ve epidemiyoloji, diyabet ekibi ve hasta eğitimi, diyabetik ayakta klinik değerlendirme, diyabetik nöropati, diyabetik ayak ülseri, diyabetik ayakta CNO, diyabetik ayakta infeksiyon, periferik vasküler hastalığın (PVH) diyabetik ayak üzerine etkisi, diyabetik ayak ile ampütasyon ve ölüm oranı ilişkisi, ayrıca ana tedaviye yardımcı tedavi yöntemleri anlatılacaktır.

\section{DEMOGRAFIK BILGILER VE EPIDEMIYOLOJi}

Diyabet hastalı̆̆ııın yaygınlığı Batı ülkelerinde \%12, Amerika'da \%3 ve Hindistan'da \%4,3 olarak bildirilmektedir. ${ }^{[1,2]} \mathrm{PVH}, \mathrm{PN}$, ayak ülseri ve alt ekstremite ampütasyonu diyabet hastasında diyabeti olmayanlara göre iki kat daha fazladır. ${ }^{[3]}$ Travma dışı ampütasyonların \%80'inin etiyolojisi diyabetik ayaktır ve ekstremite ampütasyonu diyabet hastalarında genel popülasyona göre 10-30 kat daha sık gözlenir. ${ }^{[3]}$ Diyabetik ayak patolojilerinden PN sıklığı \%50 (5 yılın üzerinde diyabeti olanlarda \%60'tan, 10 yılın üzerinde diyabeti olanlarda \%70'ten fazla), diyabetik ayak ülseri sıklı̆̆ı \%2,5-10,7, diyabetik ayak infeksiyonu sıklığı \%9, CNO sıklığı \%12,5 , diyabetik ayak ampütasyonu sıklığı \%0,25-1,8 olarak tahmin edilmektedir. ${ }^{[4,5,6]}$ Diyabetik ayak ampütasyonu sonrası ölüm oranı birinci yılda \%13-40, üçüncü yılda \%35-65, beşinci yılda \%39-80'dir ve prognozu birçok maligniteden daha kötüdür. ${ }^{[3]}$

\section{DIYABETIK AYAK EKIBI VE HASTA EĞіTiMi}

Diyabetik ayak tedavisinde multidisipliner bir yaklaşım gerekmektedir. "Diyabet polikliniği”" adı altında oluşturulan poliklinik bünyesinde hastaları aile hekimliği uzmanı, iç hastalıkları uzmanı ya da endokrinolog izler. Bu hastalardan diyabetik ayak patolojileri olanlar ortopedi ve travmatoloji uzmanına yönlendirilirler. Ortopedi ve travmatoloji uzmanı bu hastaların klinik değerlendirmesini diyabet polikliniğinde yapmalıdır. Ortopedi muayenesi sırasında hastayı yönlendiren diyabet polikliniği doktoru ve infeksiyon hastalıkları uzmanı da bulunmalı; bu üçlü ekip etkileşim halinde olmalıdır. $\mathrm{Bu}$ ekibin ortak kanaatine göre hastalardan dermatoloji, plastik cerrahi, damar cerrahisi konsültasyonu istenebilir. Özelleşmiş "diyabet hemşiresi" ise ayak bakımını anlatır ve hasta ile yakınlarını eğitir (Tablo 1).

Tablo 1. Hemşirenin hastaya ve yakınlarına verdiği eğitim

- Her gün ayağını ayna ile gözler görmüyorsa bir yakınının yardımıyla kontrol et.

- Her gün ayağını yıka, kullandığın suyun sıcaklığını dirseğinle kontrol et, soğuk sudan ve cildini yakacak kadar sıcak sudan uzak dur, ayağını ve parmak aralarını iyice kurula.

- Parmak araları dışında tüm ayağını ince bir katman halinde vazelinle yağla, ayağının kurumasını ve nasır oluşmasını önle.

- Çıplak ayak dolaşma.

- Pamuklu çorap giy, sürtünmesi yüksek olan naylon ya da yünlü çorap, file ya da desenli çoraplar giyme; dikişi az, konçu yumuşak lastikli çorapları seç.

- Çorabını günlük değiştir, temiz ve kuru olsun.

- Ayakkabı giyerken içini mutlaka kontrol et.

- Suni deri, naylon ve lastikten yapılmış ayakkabıları giyme, deriden yapılmış ayakkabı giy; parmak ucu daralan ve topuklu ayakkabılar giyme, parmak alanı derin ve geniş, topuğu iyi saran ve tabanlıklı ayakkabılar giy.

- Yeni ayakkabı alırken ayağın hacminin arttığı günün geç saatleri seçilmeli, ölçüsü aldırılmalı; eski ayakkabını yanında bulundurarak eski ve yeni ayakkabıyı dönüşümlü giy; yeni ayakkabını 2 saat/gün giyerek başla, süreyi tedrici arttırarak 1 hafta içerisinde tam zamanlı kullanıma geç.

- Termofor kullanma, ayağını kalorifer dahil hiçbir ısıtıcıya dayama.

- Basit görünen bir ayak travması ya da ülser öncesi lezyonu (kızarıklık, sıcaklık artışı ya da içi su dolu kesecik) için hemen diyabet polikliniğine başvur.

- Nasır, tırnak batması, cilt sertlikleri ya da nasıra sakın kendin müdahale etme, tıbbi yardım al.

- Tırnaklarını düz kes, köşelerini kesme.

- Antiseptik solüsyon, nasır ilacı ve benzeri, ısıtıcı ped, sivri aletler kullanma.

- Sigara içme.

- Bağdaş kurup oturma. 
Multidisipliner yaklaşımın diyabetik ayak olgularında ampütasyonu \%40-85 oranında ${ }^{[7]}$, ana önlemler alınmak kaydıyla hasta ve yakınlarının periyodik olarak eğitiminin diyabetik ayak ülseri ve ampütasyonlarını \%50'ye varan oranda ${ }^{[8]}$ azaltabileceği bildirilmiştir.

\section{DIYABETIK AYAKTA KLINIK DEĞERLENDIRME[9]}

\section{1. Öykü}

Geçmişe ait öykü (geçirilmiş ülser, ampütasyon, CNO, vasküler cerrahi, sigara), nöropatik belirtiler (ayakta yanma, elektriklenme, keskin ağrılar ya da ayağını hissetmeme), vasküler belirtiler (klaudikasyon, istirahat ağrısı, iyileşmeyen ülser) ve diğer diyabet komplikasyonları (renal, retinal, kardiovasküler) sorgulanır.

\section{Genel inspeksiyon}

Diyabetik ayak ülserinin en sık etkeni uygun olmayan ayakkabı ve çorap kullanımıdır. Hastanın giydiği ayakkabı ve çorap kontrol edilir.

\section{Dermatolojik değerlendirme}

Cilt durumuna (rengi, kalınlığı, kuruluğu, çatlaklar), terleme olup olmadığına, infeksiyona (parmak aralarında mantar infeksiyonu), ülsere, kallozite ve bül oluşumuna bakılır.

\section{Kas-iskelet sistemi değerlendirmesi}

Deformite (pençe parmak, belirgin metatars başları, Charcot ayağı (en tipik görüntü kayık ayak), kas kaybı (metatarslar arası çöküntü) gözlenir.

\section{Nörolojik değerlendirme}

Koruyucu duyunun değerlendirmesi için beş test tarif edilmiştir.

1. 10-g monofilament (Semmes-Weinstein testi) basınç duyusunu test eder.

2. $128 \mathrm{~Hz}$ diyapazon - titreşim duyusunu test eder. Test yeri, ayak başparmağının ucudur.

3. İğne duyusu - dokunma duyusundan sivri cisimleri ayırt edebilmeyi test eder. Test yeri ayak parmaklarının dorsumunda tırnağın başladığı yerin hemen proksimalidir.

4. Ayak bileği refleksleri

5. Titreşim algılaması eşik testi (Vibration perception threshold $=$ VPT testing) - titreşim duyusunu ölçen diğer bir testtir. "Biothesiometer" cihazı ile ayak parmak ucundan ölçülür. VPT $>25$ testin anormal olduğunu gösterir.
Sıklıkla 10-g monofilaman testi ile diğer testlerden yalnız birini uygulamak yeterlidir. Bir ya da birden fazla testin pozitif olması $\mathrm{PN}$ olduğunu, iki testin negatif olması PN olmadığını gösterir.

\section{Vasküler değerlendirme}

Palpasyonla ayak nabızlarına (dorsalis pedis ve tibialis anterior) bakılır ve ankle-brachial index ( $\mathrm{ABI}$ ) ölçülür. $A B I$ Doppler ile ölçülen ayak bileği (dorsalis pedis ve tibialis posterior basınçlarının yüksek olanı) sistolik basıncının brakial arter sistolik basıncına bölünmesiyle bulunur. ABI'nın normal değerleri 0,9-1,3 arasıdır. $A B I$ değerinin 0,9 'dan düşük olması periferik vasküler hastalığı, 0,8 'den düşük olması klaudikasyonu, 0,4 'ten düşük olması ise doku nekrozunu gösterir ve istirahat ağrısı eşlik eder. $A B I$ değerinin 1,3'ten yüksek olması ise arter duvarında mediyal skleroz ("tunica media" kalsifikasyonu = Mönckeberg sklerozu) vardır ve arter duvarı esnekliğini kaybetmiştir. $A B I$ değeri 1,3 'ten yüksek olan olgularda ayak parmağı sistolik basıncı ve transkutanöz oksijen basıncı $\left(\mathrm{TcPO}_{2}\right)$ ölçülmesi uygun olur.

\section{Diyabetik ayak risk kategorisinin belirlenmesi}

Diyabetik ayak risk gruplarının belirlenmesi, hastalığın prognozunu ve hastaların hangilerinin daha yakın takibe alınmasını belirlediğinden, önem taşımaktadır. Risk grupları ilk olarak 2001'de International Working Group on the Diabetic Foot (IWGDF) tarafindan belirlenmiş, 2008 tarihinde yenilenerek Texas riskli ayak sınıflandırması ortaya atılmıştır (Tablo 2). ${ }^{[10,11]}$ Texas sınıflandırmasında IWGDF sınıflandırmasına göre en önemli farklılık, PVH alt grubunun komplikasyonlarının $\mathrm{PN}+$ deformite alt grubuna göre anlamlı derecede yüksek olduğu tespit edildiği için PVH'nin ayrı bir risk grubu (Grup 2) halinde belirlenmesidir. Bu sınıflandırmaya göre Grup 2, 3 ve 4 olgular diyabetik ayakların \%20'sini oluştururlar, buna karşın ülserlerin \%70'i, ampütasyonların \%90'ı bu gruplardaki hastalarda olmaktadır. Günümüzde her iki sınıflandırma da kullanılmakta ve ortak görüş olarak risk grupları arttıkça ülser, infeksiyon, ampütasyon riskleri ile hastanede yatırılma zorunluluğunun anlamlı derecede arttığı kabul edilmektedir.

\section{DiYABETIK AYAKTA GENEL TEDAVI ŞEMASı}

IWGDF risk sınıflandırmasına göre Grup 0 hastalarda yıllık ayak muayenesi yeterlidir, özellikli bir ayakkabıya gerek yoktur. Grup 1 hastalarda ayağa tam oturan ölçüye göre ayakkabı, Grup 2 ve 3 hastalarda tabanlıklı ya da ortezli özel yapım ayakkabılar (rockerbottom shoe = kayık tabanlı veya beşik tabanlı ayakkabı, extra-depth shoe = ayak ön kısmı derinliği fazla olan 
Tablo 2. Diyabetik ayak risk grupları

\begin{tabular}{clll}
\hline Risk grubu & International Working Group on Diabetic Foot (IWGDF) & Texas & İzleme sıklı̆̆ı \\
\hline Grup 0 & PN yok & PN yok & $1 \times 1 /$ yıl \\
Grup 1 & PN & PN & $2 \times 1 / y ı l$ \\
Grup 2 & PN+deformite+PVH & PVH & $4 \times 1 / y ı l$ \\
Grup 3 & Ülser ya da ampütasyon öyküsü & Ülser öyküsü & $4-12 \times 1 /$ yıl \\
Grup 4 & & Ampütasyon öyküsü & $4 \times 12 / y ı l$
\end{tabular}

ayakkabı, rehabilitasyon ayakkabısı gibi) önerilmektedir. ${ }^{[3,12]}$ PVH'si olmayan olgularda diyabetik ayak cerrahi girişim sınıflandırması ileri sürülmüştür. ${ }^{[13]}$ Buna göre; Sınıf I elektif (PN olmayan hastada ağrılı deformite için), Sınıf II profilaktik (PN + hastada ülser ya da tekrar ülser gelişimini önlemek için), Sınıf III küratif (ülseri olan hastada ülserin iyileşmesi için) ve Sınıf IV acil (akut bir infeksiyonun ilerlemesini durdurmak için) girişimleri tarif etmektedir. PVH'si olan olgularda ise yapılacak cerrahi girişimin aciliyeti olup olmadığına bakılmalı ve gerekirse girişimden önce ya da beraberinde revaskülarizasyon düşünülmelidir.

\section{DIYABETIK NÖROPATI}

Diyabetik nöropati; distal simetrik periferik nöropati, proksimal nöropati, kranial ya da trunkal nöropati ve mononöropati multipleks olarak görülebilir. En sık karşılaşılan, \%75 oranıyla distal simetrik periferik nöropatidir. ${ }^{[1]}$ PN motor, sensoryel ve otonomik nöropati olarak karşımıza çıkar. Motor nöropati ayak arklarının bütünlüğünü bozduğu için ayağın belli noktalarında basınç artar. Sensoryel nöropati bu artan basınç alanlarını hastanın hissetmesine engel olur, mikrokırıklar ve deformite oluşur. Duyudan yoksun ayakta tekrarlayan mikrotravma bağ laksitesine, eklemlerin instabilitesine ve kemik yıkımına (nörotravmatik teori); otonomik nöropati ise sempatik denervasyona, vasküler yataktaki düz kasların gevşemesine, kemikte kan akımının artmasına ve osteolize neden olur (nörovasküler teori). ${ }^{[14]}$

\section{DIYABETIK AYAK ÜLSERI}

Diyabet hastasında yaşam boyu ayak ülseri oluşması riski \%25 olarak bildirilmektedir. İyileşmiş diyabetik ayak ülserinin 5 sene içerisinde tekrar etme olasılığı \%70'dir. ${ }^{[15]}$ Diyabetik ayak ülseri için risk faktörleri, geçirilmiş ayak ülseri, geçirilmiş alt ekstremite ampütasyonu, PN, PVH, deformite, görme yetisinin bozulması, diyabetik nefropati (özellikle diyalize giren hastalar), glisemik kontrolün bozulması ve sigara içilmesidir. ${ }^{[8]}$
Diyabetik ayak ülserinin iyileşmesini olumsuz yönde etkileyen etmenler ise ileri yaş, erkek cinsiyet, ülserin boyutları (ne kadar büyük ve derinse o kadar kötü), kalp yetersizliği, yardımsız ayakta duramayan ya da yürüyemeyen hastalar, son evre böbrek yetersizliği, $\mathrm{PN}$ ve PAH (periferik arteriyel hastalık) olarak bildirilmektedir. ${ }^{[16]}$

Diyabetik ayak ülserlerinin \%70-90'ı ayağın ön kısmında görülür; sıklık sırasına göre topuk ve ayağın ortası bunu izler. ${ }^{[11]}$ En sık kullanılan ülser sınıflandırmaları Wagner ${ }^{[17]}$, Brodsky ${ }^{[18]}$, University of Texas ${ }^{[19]}$, PEDIS ${ }^{[20]}$ ve SINBAD ${ }^{[21]}$ sınıflandırmalarıdır (Tablo 3). Diyabetik ayak ülserinde prognoza yönelik diyabetik ülser şiddet skoru (diabetic ulcer severity score - DUSS) tarif edilmiştir (Tablo 3). ${ }^{[22]}$ Buna göre her bir olumsuz ölçütün yara iyileşmesi olasılığını istatistiksel olarak anlamlı derecede düşürdüğü tespit edilmiştir; şiddet skoru 0 olan olgularda iyileşme oranı \%93, 4 olan olgularda \%57 olarak bulunmuştur. Şiddet skorunun 1 puan artması ülserin iyileşme olasılığını \%35 azaltmıştır.

Diyabetik ayak ülserlerinin yüzeysel olanları için pansuman ve yara iyileşene kadar pansuman terliği kullanmak yeterlidir (Şekil 1). Pansuman gün aşırı yapılmalıdır. Yara ve çevresi povidon iyot \%10 ile silindikten sonra sadece yara içine serum fizyolojikle ıslatılmış gaz konulmalı, üzeri kuru steril gazlarla kapatılmalıdır. Gazlar cilde flasterle yapıştırılmamalı, doğrudan elastik bandajla sarılmalıdır. Hasta, yara kapanana kadar pansuman terliği giymelidir; ülser iyileştikten sonra da yaklaşık bir ay pansuman terliğine devam etmeli, ondan sonra tabanlıklı ya da ortezli özel yapım ayakkabılara geçmelidir. Diyabetik ayakkabıya geçerken, diyabetik ayakkabı - pansuman terliği ikişer saat dönüşümlü olarak giyilerek başlanılmalı ve ayakkabı giyilen süre tedrici olarak arttırılmalıdır. Bu dönemde hastanın ayağı tekrar ülser açılması riskine karşı yakın izleme alınmalıdır.

Diyabetik ayak ülserlerinin derin olanlarında ise infeksiyon varsa debridman yapılır, derin doku kültürü alınır ve buna göre antibiyotik tedavisine başlanır. İnfeksiyon olanlar için debridmandan hemen sonra, infeksiyon olmayanlar için doğrudan tam temaslı alçı uygulanır (Şekil 2). Tam temaslı alçıya ülser kapanana 
Tablo 3. Diyabetik ayak ülseri sınıflandırmaları

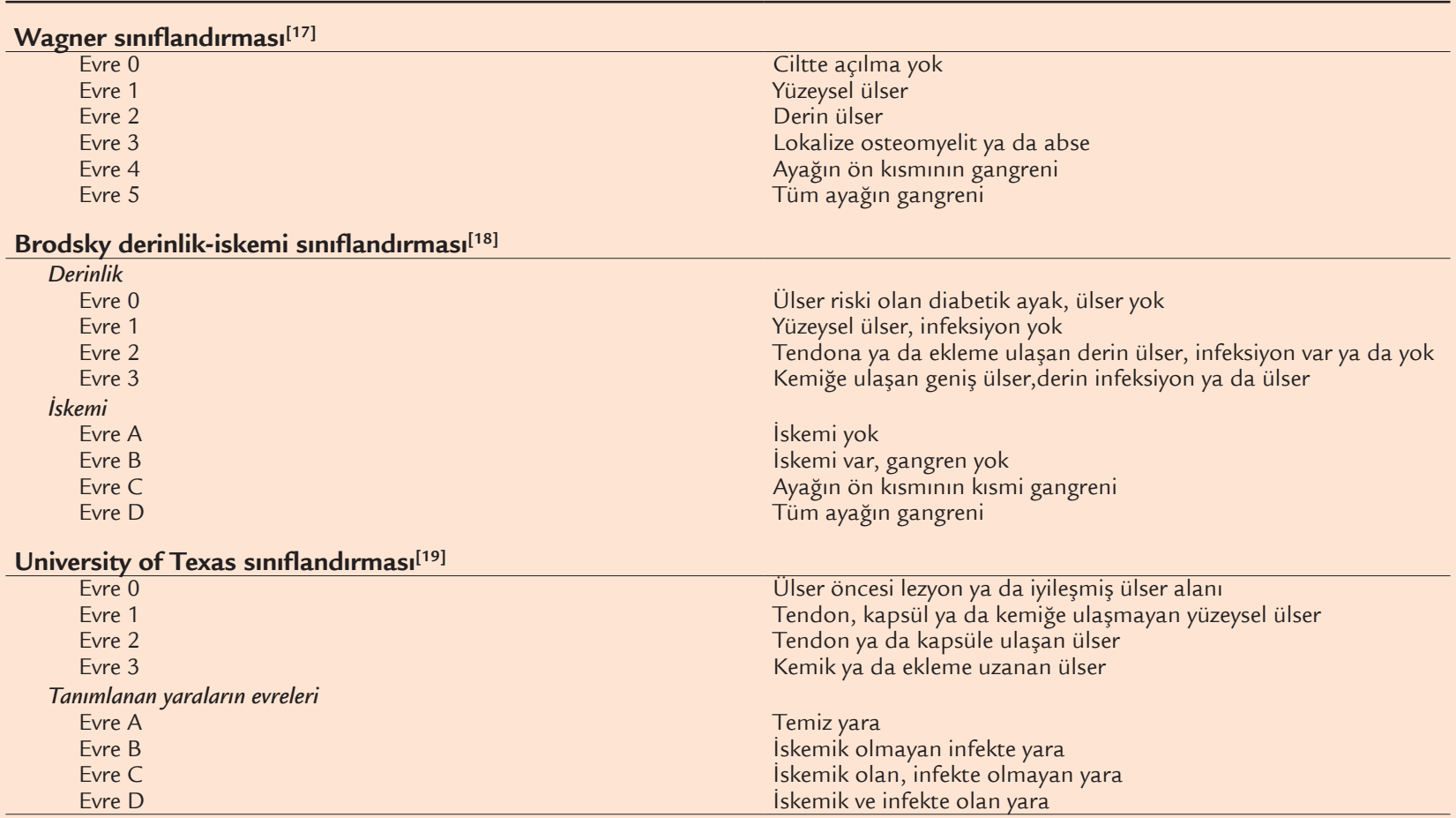

PEDIS (Perfusion-Extent/size-Depth/tissue loss-Infection-Sensation) ${ }^{[20]}$ perfüzyon, ülserin boyutu, ülserin derinliği ve doku kaybı, infeksiyon ve duyu ölçütlerini göz önüne alan ve bilimsel araştırmalara yönelik ayrıntılı bir sınıflandırmadır.

SINBAD (Site-Ischemia-Neuropathy-Bacterial infection-Area-Depth) sınıflandırması ${ }^{[21]}$
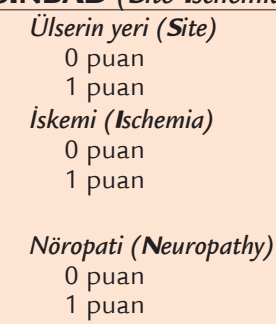

Bakteriyel infeksiyon (Bacterial infection)

0 puan

1 puan

Ülserin kapladığı alan (Area) - birbirine dik iki en uzun genişlik alınarak 0 puan

1 puan

Ülserin derinliği (Depth)

0 puan

1 puan

$\geq 3$ puan, prognozu kötü, riskli diabetik ayak

\section{Ayağın önü}

Ayağın ortası ya da arkası

Ayağın ana damarlarının en az birinde nabız var

Ayağın ana damarlarının hiçbirinde nabız yok, doku perfüzyon bozukluğu bulguları var, gangren var ya da yok

Yok (Semmes-Weinstein testi + )

Var (Semmes-Weinstein testi -)

Yok

Var

$\leq 1 \mathrm{~cm}^{2}$

$>1 \mathrm{~cm}^{2}$

Yüzeysel-cilt ve cilt altı yağ dokusuna sınırlı ülser

Derin-tendon, periost, eklem kapsülü ya da kemiğe ulașan ülser

\section{DUSS (Diabetic Ulcer Severity Score) ${ }^{[22]}$}

$\begin{array}{ll}\text { Ayak bileği arterlerinde nabız } & \\ 0 \text { puan } & \text { Yok } \\ 1 \text { puan } & \text { Var } \\ \text { Ülserden kemiğe probla ulaşılması } & \\ 0 \text { puan } & \text { Ulaşıılmıyor } \\ 1 \text { puan } & \text { Ulaşılıyor } \\ \text { Ülserin yeri } & \\ 0 \text { puan } & \text { Ayak parmakları } \\ 1 \text { puan } & \text { Ayak } \\ \text { Ülserin sayısı } & \\ 0 \text { puan } & \text { Tek } \\ 1 \text { puan } & \text { Birden fazla }\end{array}$



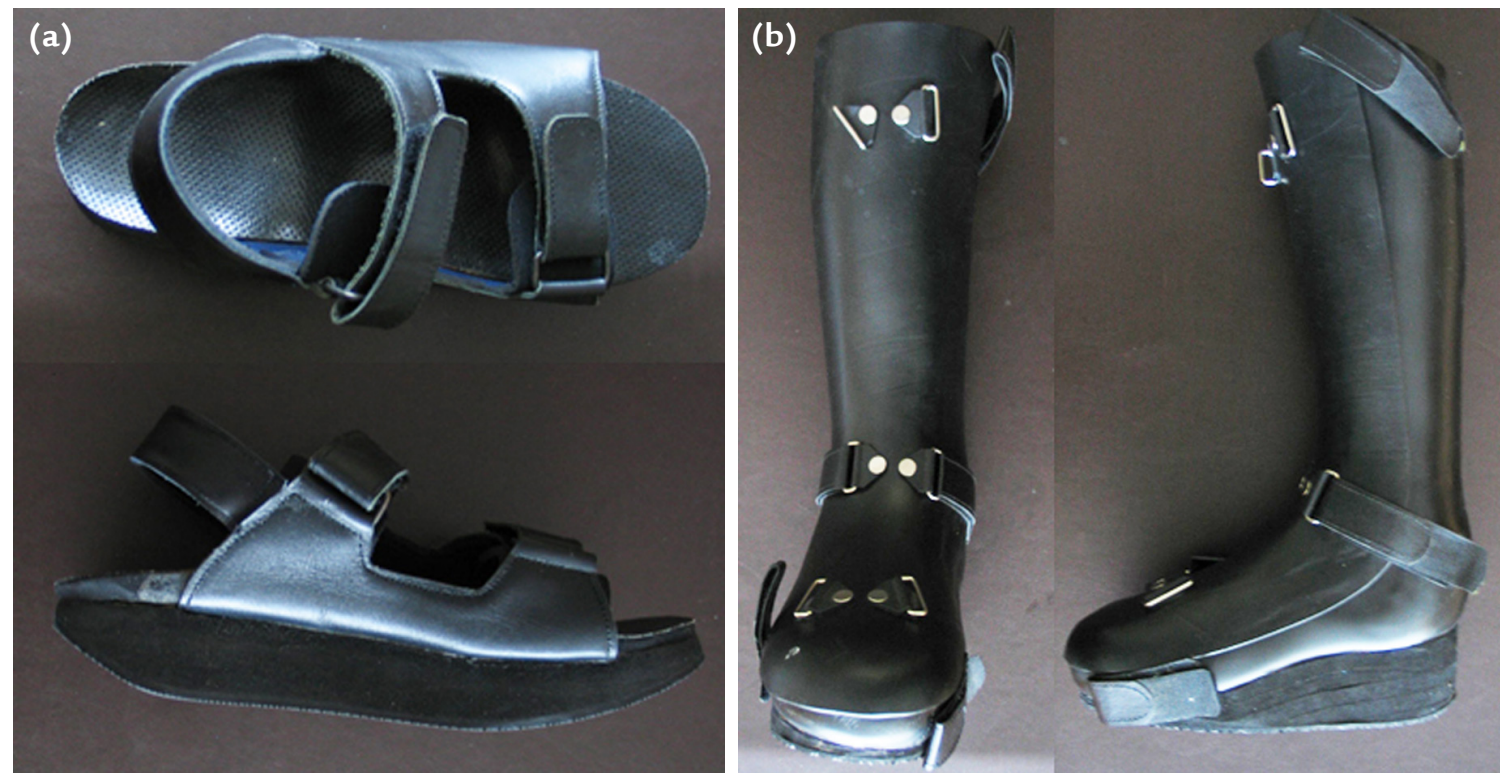

Şekil 1. Diyabetik ayakta kullanılan ortezler: Pansuman terliği (a). Tam temaslı cihaz (b).
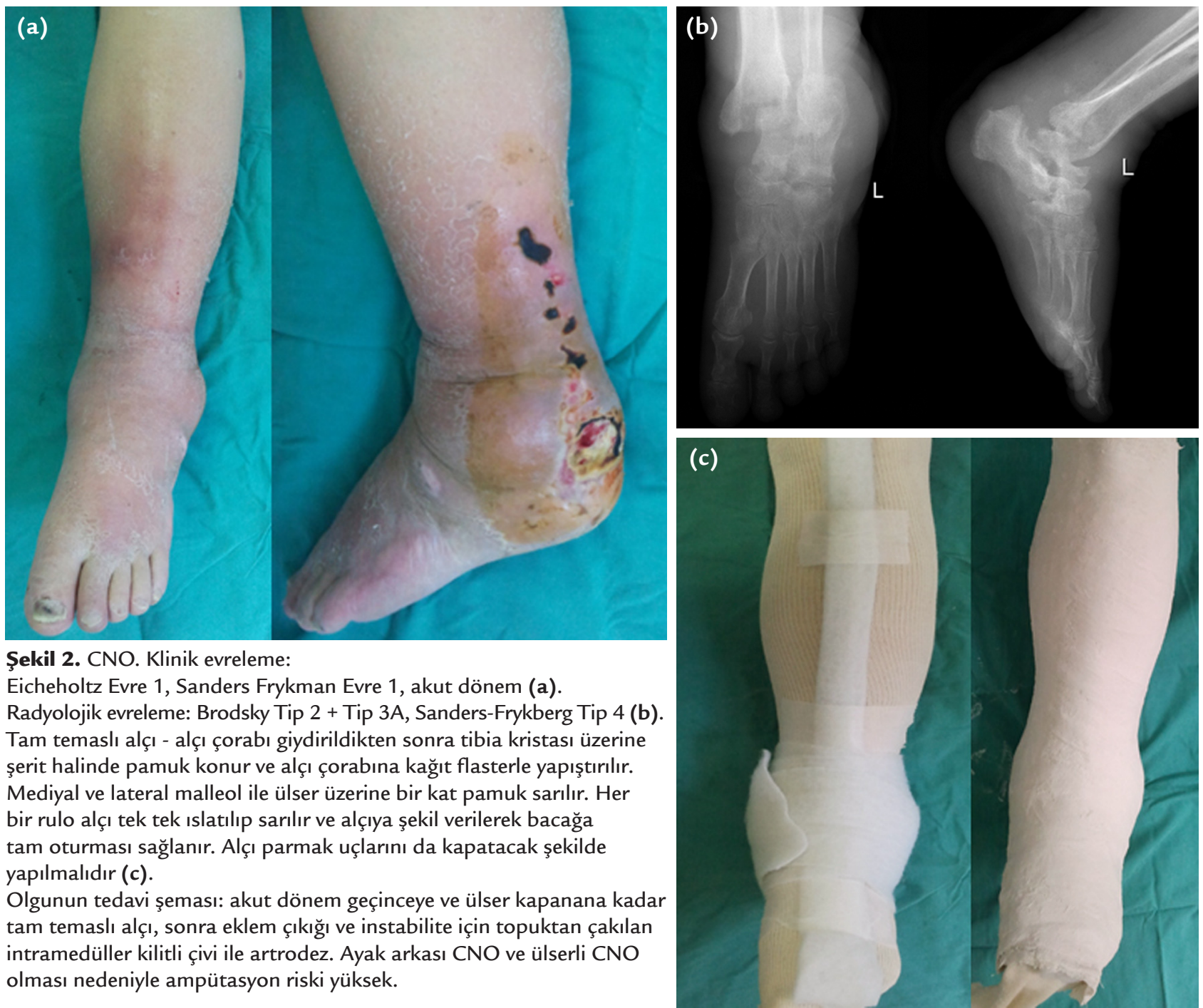

Şekil 2. CNO. Klinik evreleme:

Eicheholtz Evre 1, Sanders Frykman Evre 1, akut dönem (a).

Radyolojik evreleme: Brodsky Tip 2 + Tip 3A, Sanders-Frykberg Tip 4 (b). Tam temaslı alçı - alçı çorabı giydirildikten sonra tibia kristası üzerine şerit halinde pamuk konur ve alçı çorabına kağıt flasterle yapıştırılır. Mediyal ve lateral malleol ile ülser üzerine bir kat pamuk sarılır. Her bir rulo alçı tek tek ıslatılıp sarılır ve alçıya şekil verilerek bacağa tam oturması sağlanır. Alçı parmak uçlarını da kapatacak şekilde yapılmalıdır (c).

Olgunun tedavi şeması: akut dönem geçinceye ve ülser kapanana kadar tam temaslı alçı, sonra eklem çıkığı ve instabilite için topuktan çakılan intramedüller kilitli çivi ile artrodez. Ayak arkası CNO ve ülserli CNO olması nedeniyle ampütasyon riski yüksek. 
kadar devam edilir. Alçı değişimi alçının ıslanmasına ve ülser infekte ise infeksiyon durumuna göre 3-15 günde bir değiştirilir. Ülser iyileşince pansuman terliğine geçilir ve yukarıda belirtilen protokol uygulanır.

\section{DIYABETIK AYAKTA CNO}

CNO ilk olarak 1868 'de Jean-Martin Charcot tarafından "denervasyona bağı eklem destrüksiyonu" olarak tanımlanmıştır. ${ }^{[23]}$ Tanımı yaparken ilk olgu bildiriminin Amerikalı doktor John Kearsley Mitchell tarafından 1831 tarihinde yapıldığını da belirtmiştir. Mitchell'in olgusu spinal kordu tutan tüberküloz ${ }^{[24]}$, Charcot'un olgusu ise sifilizdi[23].

CNO sinir sistemini tutan tüm hastalıklarda görülebilir; ancak günümüzde diyabet hastalığı CNO nedeni olarak birinci sırada yer almaktadır. ${ }^{[25]}$ CNO tüm diyabet hastalarının \%0,15-2,5'inde görülür; \%30 olguda bilateraldir. ${ }^{[26]}$ CNO'da ülser gelişme riski $\% 40-63$ olarak bildirilmektedir. ${ }^{[13,27]}$

CNO'nun moleküler düzeydeki patogenezinde ${ }^{[28]}$, glukoz metabolizmasının bozulması (serbest radikaller, ileri glikasyon son ürünleri [AGE (advanced glycation end-products)], hiperlipidemi), minör travma ve nöropatik kırığın açığa çıkardı̆̆ı proinflamatuvar sitokinler TNF- $\alpha$ (tumor necrosis factor-alpha) ve IL-1 $\beta$ (interleukin 1 beta) yer almaktadır. Bu sitokinler RANKL/OPG (receptor activator nuclear factor kappa B ligand / osteoprotegerin) sitemini aktive eder. RANKL ekspresyonunun artması NF-KB (nuclear transcription factor kappa B) aktivasyonuna, bu da osteoklast olgunlaşmasının hızlanmasına ve osteolize neden olur. Moleküler düzeydeki bu reaksiyonları dengeleyen sinir uçlarından salgılanan RANKL antagonisti CGRP (calcitonin gene related peptide) miktarı da polinöropati nedeniyle azaldığından yıkım daha da artmaktadır. Diğer yandan, RANKL/NF-KB döngüsü arter duvarındaki düz kasları da etkileyerek CNO'lu hastaların \%90'ından fazlasında görülen vasküler kalsifikasyona (Mönckeberg sklerozu) neden olur. ${ }^{[29]}$ Mönckeberg sklerozu ve sempatik denervasyon periferik vasküler dirençte azalmaya, arteriovenöz şanta ve hiperemiye yol açmaktadır. Arteriovenöz şant ve buna ek olarak pankreastan salınan kemiğin büyüme faktörleri olarak gösterilen insülin ve amilin (iselet amyloid polypeptide) düzeylerindeki azalma osteopeniye neden olmaktadır. ${ }^{[29]}$ Sonuç olarak CNO patogenezinde kontrolsüz inflamasyon, diyabetik nöropati, mikrovasküler işlev bozukluğu ve osteopeni yer almaktadır.

CNO'nun anatomik sınıflandırması Brodsky ${ }^{[30]}$ tarafindan yapılmış, Sanders ve Frykman ${ }^{[31]}$ tarafından geliştirilmiştir. Brodsky dört tip tanımlamıştır; Tip 1 ayak ortası, Tip 2 ayak arkası (subtalar, talonaviküler ve kalkaneoküboid eklemler), Tip $3 \mathrm{~A}$ ayak bileği, Tip
3B tuber calcanei'yi tutan CNO'yu tarif eder. Brodsky Tip 1'e \%60, Tip 2'ye \%30-35, Tip 3A ve Tip 3B'ye ise nadir olarak rastlanır. Sanders ve Frykberg anatomik sınıflandırmasında, Tip 1 metatarsofalangeal ve interfalangeal (\%15), Tip 2 tarsometatarsal (\%40), Tip 3 tarsal (\%30), Tip 4 subtalar ve ayak bileği (\%10), Tip 5 kalkaneal (\%5) tutulumu gösterir.

CNO'nun klinik evrelemesi Eichenholtz tarafindan yapılmıştır. ${ }^{[30]}$ Evre 1 akut inflamatuvar dönemdir, radyografide kemiklerde parçalanma, eklemlerde çıkık görülür. Klinik muayenede ayak şiş, sıcak ve kızarıktır. Evre 2 kırık parçalarda birleşme evresidir, radyografide yeni kemik yapımı görülür. Evre 3 iyileşme evresidir, kalıcı deformite ile kırık iyileşir. Sanders ve Frykberg bu sınıflandırmayı akut ve kronik olarak ikiye ayırmış; akut dönemi Evre $0=$ prodromal ve Evre $1=$ gelişme evreleri, kronik dönemi Evre 2 = birleşme ve Evre 3 = yeniden şekillenme evreleri olarak tanımlamıştır. ${ }^{[31]}$ Eichenholtz'dan farklı olarak Sanders ve Frykberg'in tanımladığı prodromal evre, radyografik bulguların olmadığı ancak manyetik rezonans ile kemik iliği ödeminin tespit edilebildiği; klinik bulgu olarak ayakta şişlik, ISı artışı ve eritemin görüldüğü evredir.

\section{Klinik}

Uzun süreli diyabet (>10 sene) hastasında ayakta ani ortaya çıkan inflamasyon (şiş, sıcak, kızarık ayak) aksi kanıtlanana kadar Charcot ayağı olarak değerlendirilmelidir. Travma, olguların 1/3'ünde vardır; travma tespit edilemeyen olguların \%35'inde ülser, diğerlerinde geçirilmiş cerrahi ve/veya osteomiyelit gözlenir. Tetikleyici etkenin tespit edilemediği olgular nadirdir. ${ }^{[32]}$

\section{Tanı}

Tüm olgularda PN vardır. CNO'da etkilenen ayak cildi sıcaklığı diğer ayağınkinden 2 derecenin üzerinde fazladır. ${ }^{[33]}$ Cilt sıcaklığı kızıl ötesi cilt termometresi ile ölçülür. Prodromal evrede tanı klinik muayene ile konur; bu evrede manyetik rezonans (MR) kemik iliği ödemini göstermesi açısından gerekebilir. Radyografik bulgu veren evrelerde genellikle başka tetkik gerekmez, ancak bazen infeksiyonla ayırıcı tanı yapmak gerekir. İnfeksiyonla ayırıcı tanıda düz bacak kaldırma testinden yararlanılabilir. ${ }^{[4]}$ CNO'dan şüphe edilen ekstremite 2 dakika kalp seviyesinin üzerinde tutulduğunda ayaktaki kızarıklık geriliyorsa CNO olarak kabul edilebilir. Şüphede kalınan ve CNO üzerine infeksiyon şüphesi olan durumlarda ayırıcı tanıda MR ve lökosit işaretli Indium 111 tetkiklerinden yararlanılabilir. Esasında bu gibi durumlarda derin doku ve kemik biyopsisi yapmak en uygun yöntemdir. ${ }^{[14]}$ 


\section{Tedavi}

Yükten kurtarma, cihazla tedavi, cerrahi tedavi ve ilaç tedavisinden söz edilecektir.

Yükten kurtarma: CNO'nun akut döneminde (prodromal evre ve gelişme evresi) tam temaslı alçı yapılır (Şekil 2). İnflamasyon gerileyene kadar haftalık alçı değişimleri yapılarak yük vermeden bu tedavi sürdürülür.

Cihazla tedavi: Akut evre geçtikten sonra kronik dönemde (birleşme ve yeniden şekillenme evreleri) tam temaslı cihaz ile tedaviye devam edilir (Şekil 1). Bu dönemde hastaya tam yük verilir. Kırık konsolidasyonu tam olarak oluştuktan sonra tabanlıklı ya da ortezli özel yapım ayakkabılara geçilir.

Cerrahi tedavi: Akut dönemde eklem çıkıkları ve instabiliteyle seyreden olgulara ve kronik dönemde ortopedik botla telafi edilemeyecek deformitelere cerrahi tedavi uygulanır. Akut dönemde ameliyatın zamanlamasında inflamasyonun gerilemesi ve ülser varsa ülserin kapanması beklenir; bu aşama tam temaslı alçı yapılarak geçirilir. İnflamasyon geriledikten ve ülser kapandıktan sonra eklem çıkıklarının redüksiyonu ve artrodez uygulanır. Artrodezler kanüllü spongiöz ya da kompresyon yapan diğer vidalarla, kompresyon yapan plak-vida sistemleriyle, intramedüller kilitli çivilerle yapılabilir. Bazı olgularda ise hastanın metabolizmasının bozukluğu nedeniyle inflamasyon kontrole alınamaz, kemik destrüksiyonunun hızla ilerlediği gözlenir. Ayağı kurtarmak için, inflamasyon gerilememesine rağmen hastaya bir şans verilir. Bu olgulara internal ampütasyon ${ }^{[34]}$ (debris materyalinin tamamının temizlenmesi) ve eksternal fiksasyon (osteolizin ve osteopeninin fazla olması nedeniyle internal tespit materyallerinin yetersizlĭgi olacağından) uygulanır (Şekil 3). Kronik dönemdeki deformitelere Aşil
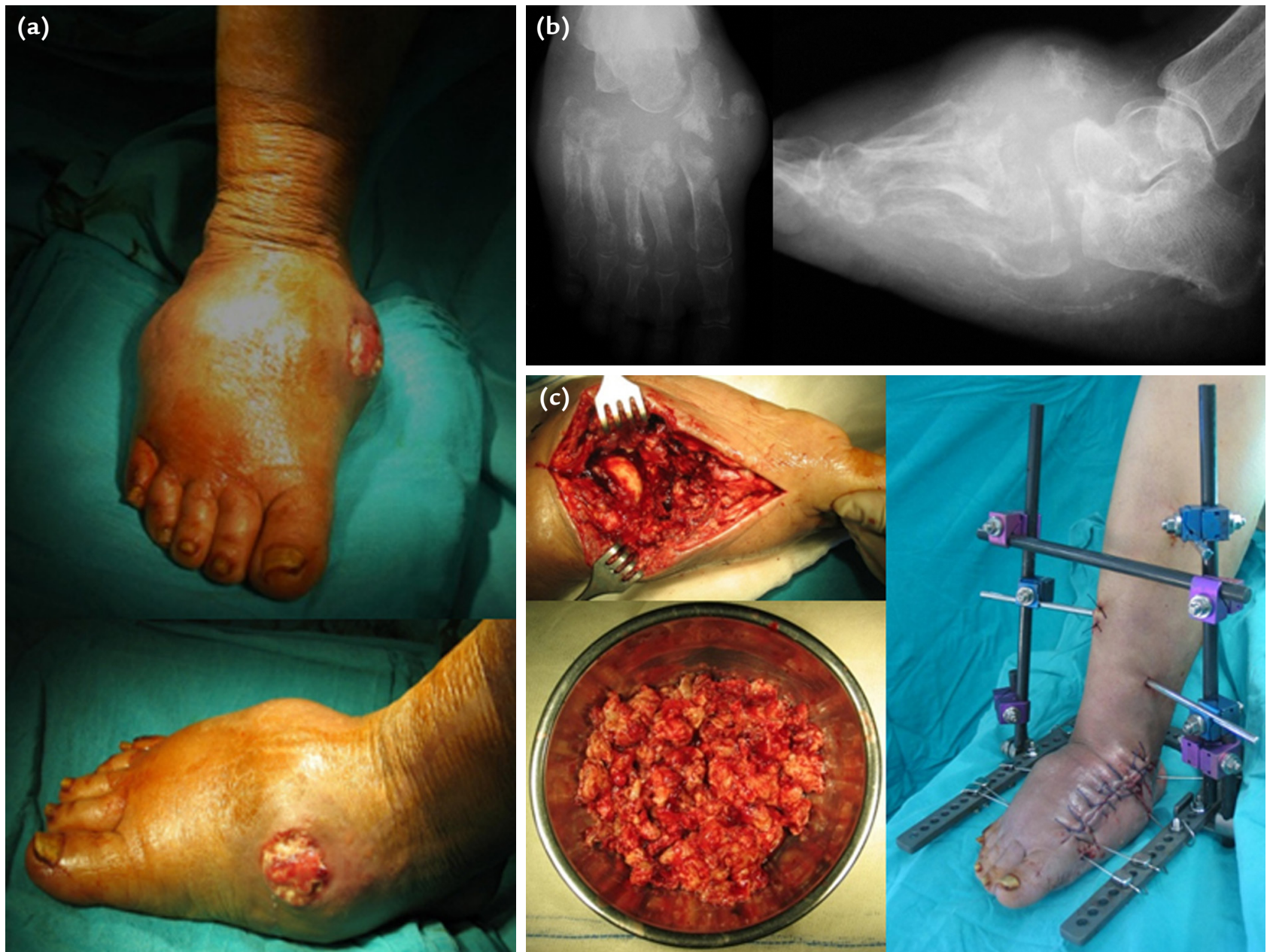

Şekil 3. İnternal ampütasyon: İnflamasyonun tam temaslı alçı ve sonrası breyse rağmen gerilemediği olgu, son dönem böbrek yetersizliği +, metabolizma bozuk (a). Radyografik olarak osteolizin ayak ortası ve subtalar ekleme yayıldığı ve durdurulamadı̆̆ı görülüyor (b). İnternal ampütasyon (tasın içinde çıkarılan tüm debris materyali) + eksternal fiksatör uygulaması (c). Olgunun akıbeti: Ameliyat sonrası dördüncü ayda infeksiyon nedeniyle diz altı ampütasyon, 1 yıl sonra exitus. 
uzatması, ekzostektomi ve deformite düzeltici girişimler yapılabilir. Gangren ve/veya kontrol altına alınamayan infeksiyonlarda ampütasyon gündeme gelir.

İlaç tedavisi: Kemik yıkımını önlemek için bifosfonatlar ve kalsitonin kullanılabilir. Nöropatiyi önlemek için PKC (proteinkinase C) inhibitörleri, immunofilinler, nörotropik ilaçlar, ACE (angiotensin converting enzyme) inhibitörleri, antioksidanlar, AGE blokerleri/yıkıcıları ve prostoglandinler kullanılmaktadır. Deneme aşamasındaki ilaçlar "kontrolsüz inflamasyonu" önlemek için geliştirilmektedir. Bunların içinde RANKL antagonisti denosumab, TNF- $\alpha$ antagonisti infliximab ve etanercept, CGRP (calcitonin gene related peptide) ve VEGF (vascular endothelial growth factor) agonistleri sayılabilir. ${ }^{[35]}$

\section{DIYABETIK AYAKTA INFEKSIYON}

Diyabetik ayak ülserinin en sık rastlanılan ve en ciddi komplikasyonu infeksiyondur. Bir grup diyabet hastasında iki yıl içerisinde diyabetik ayak infeksiyonunun $\% 9$ oranında geliş̧tiği; IWGDF risk grubu 0 olgularda bu oranın \%1,6, IWGDF risk grubu 1, 2 ve 3 olgularda $\% 19,6$ olduğu bildirilmiştir. ${ }^{[36]}$

Diyabetik ayak infeksiyonlarında risk faktörlerinin başında kemiğe ulaşan diyabetik ayak ülserinin geldiği; sonra sırasıyla, 30 günün üzerinde iyileşmeyen ülserler, tekrarlayan ülserler ve PVH'nin yer aldığı bildirilmiştir. ${ }^{[36]}$ Diğer bir çalışmada ise geçirilmiş ampütasyon öyküsünün en önemli risk faktörü olduğu ileri sürülmüştür. ${ }^{[7]}$

Diyabetik ayak infeksiyonunda sistemik bulgular genellikle yoktur; şişlik, eritem ve sıcaklık artışı (pürülan akıntının olduğu ya da olmadığı) gibi lokal bulgular vardır, ancak bu lokal bulguların da diyabetin genel seyrindeki PVH, PN ve lökosit disfonksiyonu nedeniyle silinebileceği unutulmamalıdır.

Diyabetik ayak infeksiyonlarının çoğunluğu yumuşak doku infeksiyonudur. Osteomiyelit görülme sıklığı ise \%20 olarak bildirilmiştir. Bununla birlikte infekte diyabetik ayak ülserlerinin \%60'ında osteomiyelit vardır. ${ }^{[36]}$ Ülser kemik çıkıntılarının üzerindeyse, 1-2 hafta içerisinde iyileşmezse ve boyutları ile derinliği artıyorsa osteomiyelit riski artar. "Sosis parmak" deformitesi varsa osteomiyelit olarak kabul edilebilir.

Laboratuvar bulgularında nötrofil sayısı ve C-reaktif protein (CRP) yüksekliği yumuşak doku infeksiyonunu, sedimentasyon yüksekliği ise osteomiyeliti düşündürmelidir. ${ }^{[14]}$ Diyabetik ülserde osteomiyelit tanısı için "probe to bone" (PTB) testi yapılmalıdır. Ülsere sokulan bir sonda yardımıyla ülser derinliği ve ülserin ulaştığı anatomik yapılar incelenir. PTB testinde sonda kemiğe ulaşmıyorsa osteomiyelit olmama olasılığı \%98'dir, ulaşıyorsa osteomiyelit olma olasılı̆̆ı \%62'dir. Bu test ülserli bir olguda osteomiyelit olmadığını çok yükssek bir oranda tespit edebilmektedir. ${ }^{[37]}$

Tipik klinik bulgulara ilave olarak radyografik bulgular da varsa osteomiyelit tanısı konulabilir. Ancak osteomiyelitin erken döneminde (ilk 10-20 gün) radyografik bulgu yoktur. Bu dönemdeki radyolojik tanıda lökosit işaretli İndium sintigrafisi (duyarlılığı \%89 ve özgüllügüü \%78), MR (duyarlılığı \%90-100 ve özgüllüğü \%83) ve halen tanı için "altın standart" olan kemik biyopsisi (duyarlılığı \%95 ve özgüllügü \%99) yapilabilir. ${ }^{[14]}$

Diyabetik ayak infeksiyonu olan hastalarda yapılan bir çalışmada, ilk başvuruda alınan mikrobiyolojik örneklerin \%64'ünde bakteri üretilebildiği ve infeksiyonların \%40'ının polimikrobiyal oluğu bildirilmiştir. ${ }^{[38]}$ İzole edilen mikroplardan \%52'si gram pozitif (Staphylococcus aureus \%30, Enterococcus faecalis \%10, streptococci \%4), \% 40'ı gram negatifçomak (enterobacter\%23, Pseudomonas aeruginosa \%10) olarak tespit edilmiştir. S.aureus için cotrimoxazole, rifampin ve doxycycline, dirençli suşlar için moxifloxacin; P.aeruginosa için colistin (polymyxin E), dirençli suşlar için ciprofloxacin önerilmektedir. Diğer bir kapsamlı çalışmada ise orta ve ağır dereceli diyabetik ayak infeksiyonlarında biyopsi ile 454 örneğin 427'sinde (\%94) pozitif kültür elde edilmiş, bunlardan $\% 83,8^{\prime} \mathrm{i}$ polimikrobiyal, \%48'i yalnız aerob, \%43,7'si aerob ve anaerob ve \%1,3'ü yalnız anaerob olarak rapor edilmiştir. ${ }^{[39]}$ Aerob mikroorganizmalar Staphylococcus (\%34), Streptococcus (\%15.5), Enterococcus (\%13.5), Enterobacteriaceae (\%12.8), Corynebacterium $(\% 10,1)$ ve Pseudomonas aeruginosa $(\% 3,5)$; anaerob mikroorganizmalar ise gram pozitif koklar $(45,2 \%)$, Prevotella (13,6\%), Porphyromonas (11,3\%) ve Bacteroides fragilis $(10,2 \%)$ olarak tespit edilmiştir. Aynı çalışmada ertapenem ve piperacillin-tazobactam'ın her birinin enterik gram negatif çomaklar, metisilin-duyarlı S.aureus ve anaerobların 98'inden fazlasına etkili olduğu; anaerobların \%24'ünün (özellikle gram pozitif koklar) moxifloxacin'e, gram pozitif aerobların \%27'sinin ve Enterobacteriaceae'nın \%6'sının levofloxacin'e dirençli olduğu bildirilmiştir.

\section{DIYABET AYAK - PVH iLişKIsi}

Diyabet hatalarının \%30'unda ${ }^{[18]}$, diyabetik ayak ülseri olan hastaların \%50'sinde ${ }^{[19]} \mathrm{PVH}$ de vardır. $\mathrm{PVH}$ tanısı, palpasyonda ayak bileği arterlerinde nabız alınamaması, Doppler'de monofazik akım olması ya da akım olmaması, $A B I<0,9$ olması ile konur.

ABI 0,6'dan düşük ve ayak bileği sistolik basıncı 70 $\mathrm{mmHg}$ 'den yüksek ise ülser iyileşme olasılığı düşüktür. $A B I$,6'dan yüksek ve ayak bileği basıncı 70 mmHg'den 
yüksek ise ayak parmağı basıncı ve $\mathrm{TcPO}_{2}$ ölçülmelidir. Ayak parmağı basıncı 55 mmHg'nin ve $\mathrm{TcPO}_{2} 50$ mmHg'nin üzerinde ise ülser genellikle iyileşir. Ayak parmağı basıncı 30 mmHg'nin ve $\mathrm{TcPO}_{2} 30 \mathrm{mmHg}$ 'nin altında ise ülser iyileşme olasılığı son derece düşüktür ve revaskülarizasyon endikasyonu vardır; bu eşik değerlerin üzerinde ise ülser 4-6 hafta süreyle izlenmelidir. İzlemde yara iyileşmesi olmuyor ve kötüye gidiyorsa intraarteriyel "digital substraction angiography" (DSA) yapılmalıdır; bu tetkikte ileri dereceli PVH doğrulanırsa revaskülarizasyon yapılmalıdır. ${ }^{[40]}$

Revaskülarizasyon için en sık otolog ven alınarak by-pass ya da balon anjiyoplasti girişimleri uygulanır. İskemik ayak ülseri olan revaskülarizasyon yapılmayan olgularda birinci yılda ekstremiteyi kurtarma oranı $\% 43$, revaskülarizasyon yapılanlarda $\% 78-85$ ve ülser iyileşme oranı \%60'ın üzerinde olarak bildirilmektedir. Yaşam beklentisi $<6-12$ ay olan, zaten ağır fonksiyonel bozukluğu bulunan ve ileri dereceli doku nekrozu nedeniyle ayağın kurtarılması mümkün olmayan olgularda ise revaskülarizasyon düşünülmemelidir. ${ }^{[40]}$

\section{DIYABETIK AYAK - AMPÜTASYON}

Alt ekstremite ampütasyonlarının $\% 45^{\prime} i$ diyabet hastalarında yapılmaktadır ve diyabet hastasında ampütasyon riski diyabeti olmayanlara göre 15 kat daha fazladır. ${ }^{[41]}$ Geçirilmiş minör travma, PN, diyabetik ayak ülseri, PVH, diyabetik ayak infeksiyonu, diyabetik ayak ampütasyonu için risk faktörleridir. ${ }^{[42]}$ CNO'nun ise tek başına ampütasyon riskini arttırmadığı; CNO’lu hastalarla karşılaştırıldığında diyabetik ayak ülseri olan hastaların yedi kat, ülserli CNO hastalarının 12 kat daha fazla ampütasyon riski olduğu bildirilmiştir. ${ }^{[43]}$ Öte yandan, diyabetik ayak ampütasyonlarının çoğunluğunun nedeni $\mathrm{PVH}$ ve infeksiyondur; bunların da \%80'den fazlasında önceden bir diyabetik ayak ülseri vardır. ${ }^{[4]}$

\section{DIABETIK AYAK - ÖLÜM ORANI}

5 yıllık ölüm oranı riski, yalnız diyabeti olanlarda $\% 18,8, \mathrm{CNO}$ gelişen hastada $\% 28,3$ ve diyabetik ayak ülseri olan hastada \%37 olarak bildirilmiştir. ${ }^{[27]}$ Ölüm oranı riskinin en yüksek diyabetik ayak ülseri olan grupta gözlenmesi, bu grupta $\mathrm{PVH}$ yaygınlığının diğerlerine göre daha yüksek olmasına bağlanmıştır.

\section{ANA TEDAVILERE YARDIMCI TEDAVILER}

\section{Hiperbarik Oksijen Tedavisi (HBO)}

Destek tedavileri içinde en sık kullanılandır. HBO'nun doku hipoksisini düzelttiği, perfüzyonu arttırdığı, ödemi ve inflamasyonu azalttığı; fibroblast proliferasyonu, kollajen yapımı, anjiyogenezi teşvik ettiği düşünülmektedir. ${ }^{[6]}$ Ayrıca infeksiyona karşı bakterisid etkisi ile lökosit ve makrofaj fonksiyonlarını arttırıcı etkisi olduğu bilinmektedir. ${ }^{[45]}$

HBO tedavisi, \%100 $\mathrm{O}_{2}$ solutulan 2-2,5 ATA basınçlı odada, haftanın 5 günü, günde 90 dakikayı aşmayan tek seans uygulanmalı; bir kür 30 günden az olmamalıdır. Diyabetik ayakta HBO tedavisi, Wagner evresi 3 ve üzeri olan diyabetik ayak lezyonlarında, standart tedaviye yanıt vermeyen diyabetik ayak osteomiyelitinde ve nekrotizan infeksiyonlarında endikedir. $\mathrm{TcPO}_{2}$ ölçümü ile $\mathrm{HBO}$ tedavisinin etkili olup olmayacağı önceden tespit edilebilir. Yara çevresi $\mathrm{TcPO}_{2}$ değeri normobarik ortamda $50 \mathrm{mmHg}$ 'nin altında, hiperbarik odada 200 mmHg olmalıdır. ${ }^{[46]}$

Yakın zamanda kulak ya da sinüs cerrahisi geçiren hastalarda, epilepside, bazı kemoterapilerde, üst solunum yolu infeksiyonlarında, amfizemde, göğüs cerrahisi geçirenlerde, pnömotoraksta, "pacemaker"ı olanlarda, optik nöritte, otosklerozda, viral infeksiyonlarda, konjenital sferositoziste, hipertermide, klostrofobisi olanlarda ve hamilelerde $\mathrm{HBO}$ uygulanmamalıdır. ${ }^{[47]}$

\section{Diğer}

Yarayı ıslak tutmaya yarayan pansuman malzemeleri (Promogran, Hyalofill), yara içine enjekte edilen büyüme faktörleri (örneğin; platelet-derived growth factor [PDGF]), doku bankasından elde edilen cilt (Apligraf, Dermagraf), vakum yardımlı kapatma (vacuum assisted closure [VAC]) sistemleri sayılabilir. ${ }^{[48]}$

\section{KAYNAKLAR}

1. Bansal V, Kalita J, Misra UK. Diabetic neuropathy. Postgrad Med J 2006;82(964):95-100.

2. Boyko EJ, Ahroni JH, Stensel V, Forsberg RC, Davignon DR, Smith DG. A prospective study of risk factors for diabetic foot ulcer. The Seattle Diabetic Foot Study. Diabetes Care 1999;22(7):1036-42.

3. Singh N, Armstrong DG, Lipsky BA. Preventing foot ulcers in patients with diabetes. JAMA 2005;293(2):217-28.

4. Pinzur MS. Charcot foot arthropathy. Orthopaedic Knowledge Online Journal 2007. http://orthoportal.aaos.org/oko/ article.aspx?article $=$ OKO_FOO026\&section $=3 \& \#$ article

5. Tiaka EK, Papanas N, Manolakis AC, Maltezos E. The role of hyperbaric oxygen in the treatment of diabetic foot ulcers. Angiology 2012;63(4):302-14. CrossRef

6. Boulton AJ, Malik RA, Arezzo JC, Sosenko JM. Diabetic somatic neuropathies. Diabetes Care 2004;27(6):1458-86.

7. Peters EJ, Lavery LA, Armstrong DG. Diabetic lower extremity infection: influence of physical, psychological, and social factors. J Diabetes Complications 2005;19(2):107-12.

8. Lavery LA, Armstrong DG, Vela SA, Quebedeaux TL, Fleischli JG. Practical criteria for screening patients at high risk for diabetic foot ulceration. Arch Intern Med 1998;158(2):157-62. 
9. Boulton AJ, Armstrong DG, Albert SF, Frykberg RG, Hellman R, Kirkman MS, Lavery LA, LeMaster JW, Mills JL Sr, Mueller MJ, Sheehan P, Wukich DK; Task Force of the Foot Care Interest Group of the American Diabetes Association. Comprehensive foot examination and risk assessment. Endocr Pract 2008;14(5):576-83.

10. Peters EJ, Lavery LA; International Working Group on the Diabetic Foot. Effectiveness of the diabetic foot risk classification system of the International Working Group on the Diabetic Foot. Diabetes Care 2001;24(8):1442-7.

11. Lavery LA, Peters EJ, Williams JR, Murdoch DP, Hudson A, Lavery DC; International Working Group on the Diabetic Foot. Reevaluating the way we classify the diabetic foot: restructuring the diabetic foot risk classification system of the International Working Group on the Diabetic Foot. Diabetes Care 2008;31(1):154-6.

12. Dahmen R, Haspels R, Koomen B, Hoeksma AF. Therapeutic footwear for the neuropathic foot: an algorithm. Diabetes Care 2001;24(4):705-9.

13. Bevilacqua NJ, Rogers LC, Armstrong DG. Diabetic foot surgery: classifying patients to predict complications. Diabetes Metab Res Rev 2008;24 Suppl 1:S81-3. CrossRef

14. Giurato L, Uccioli L. The diabetic foot: Charcot joints and osteomyelitis. Nucl Med Commun 2006;27(9):745-9.

15. Apelqvist J, Larsson J, Agardh CD. Long-term prognosis for diabetic patients with foot ulcers. J Intern Med 1993;233(6):485-91.

16. Prompers L, Schaper N, Apelqvist J, Edmonds M, Jude E, Mauricio D, Uccioli L, Urbancic V, Bakker K, Holstein P, Jirkovska A, Piaggesi A, Ragnarson-Tennvall G, Reike H, Spraul M, Van Acker K, Van Baal J, Van Merode F, Ferreira I, Huijberts $M$. Prediction of outcome in individuals with diabetic foot ulcers: focus on the differences between individuals with and without peripheral arterial disease. The EURODIALE Study. Diabetologia 2008;51(5):747-55. CrossRef

17. Wagner Jr FW. A classification and treatment program for diabetic, neuropathic, and dysvascular foot problems. Instructional Course Lectures, vol 28. Rosemont, IL: American Academy of Orthopaedic Surgeons; 1979. p.143-65.

18. Brodsky JW. Outpatient diagnosis and management of the diabetic foot. Instructional Course Lectures. Rosemont, IL: American Academy of Orthopaedic Surgeons; 1993. 42:43.

19. Lavery LA, Armstrong DG, Harkless LB. Classification of diabetic foot wounds. J Foot Ankle Surg 1996;35(6):528-31.

20. Schaper NC. Diabetic foot ulcer classification system for research purposes: a progress report on criteria for including patients in research studies. Diabetes Metab Res Rev 2004;20 Suppl 1:S90-5.

21. Ince P, Abbas ZG, Lutale JK, Basit A, Ali SM, Chonan F, Morbach S, Möllenberg J, Game FL, Jeffcoate WJ. Use of the SINBAD classification system and score in comparing outcome of foot ulcer management on three continents. Diabetes Care 2008;31(5):964-67. CrossRef

22. Beckert S, Witte $M$, Wicke $C$, Königsrainer A, Coerper S. A new wound-based severity score for diabetic foot ulcers: A prospective analysis of 1,000 patients. Diabetes Care 2006;29(5):988-92.

23. Charcot JM. Sur quelques arthropathies qui paraissent dépendre d'une lésion du cerveau ou de la moëlle épinière. Arch Physiol Norm Pathol 1868;1:161-78.

24. Mitchell JK. On a new practice in acute and chronic rheumatism. Am J Med Sci 1831;8:55-64. CrossRef
25. Jeffcoate WJ, Game F, Cavanagh PR. The role of proinflammatory cytokines in the cause of neuropathic osteoarthropathy (acute Charcot foot) in diabetes. Lancet 2005;366(9502):2058-61.

26. Laughlin RT, Calhoun JH, Mader JT. The diabetic foot. J Am Acad Orthop Surg 1995;3(4):218-25.

27. Sohn MW, Lee TA, Stuck RM, Frykberg RG, Budiman-Mak E. Mortality risk of Charcot arthropathy compared with that of diabetic foot ulcer and diabetes alone. Diabetes Care 2009;32(5):816-21. CrossRef

28. Rogers LC, Frykberg RG, Armstrong DG, Boulton AJM, Edmonds M, Ha Van G, Hartemann A, Game F, Jeffcoate W, Jirkovska A, Jude E, Morbach S, Morrison WB, Pinzur M, Pitocco D, Sanders L, Wukich DK, Uccioli L. The Charcot foot in diabetes. Diabetes Care 2011;34(9):2123-9. CrossRef

29. Jeffcoate WJ. Vascular calcification and osteolysis in diabetic neuropathy - is RANK-L the missing link? Diabetologia 2004;47(9):1488-92.

30. Brodsky JW. The diabetic foot. In: Coughlin MJ, Mann RA, editors. Surgery of the foot and ankle. Eichenholtz classification; 7th ed. St. Louis: Mosby; 1999. p.895-969.

31. Sanders LJ, Frykberg RG. Diabetic neuropathic osteoarthropathy: the Charcot foot. In: Levin ME, O'Neal LW, Bowker JH, editors. The High Risk Foot in Diabetes Mellitus. New York: Churchill Livingstone; 1991. p.297-338.

32. Jeffcoate WJ. Charcot neuro-osteortropathy. Diabetes Metab Res Rev 2008;24 Suppl 1:S62-5. CrossRef

33. Armstrong DG, Holtz-Neiderer K, Wendel C, Mohler MJ, Kimbriel HR, Lavery LA. Skin temperature monitoring reduces the risk for diabetic foot ulceration in high-risk patients. Am J Med 2007;120(12):1042-6.

34. Koller A. Internal pedal amputations. Clin Podiatr Med Surg 2008;25(4):641-53. CrossRef

35. Boulton AJ, Vinik Al, Arezzo JC, Bril V, Feldman EL, Freeman R, Malik RA, Maser RE, Sosenko JM, Ziegler D; American Diabetes Association. Diabetic neuropathies: a statement by the American Diabetes Association. Diabetes Care 2005;28(4):956-62.

36. Lavery LA, Armstrong DG, Wunderlich RP, Mohler MJ, Wendel CS, Lipsky BA. Risk factors for foot infections in individuals with diabetes. Diabetes Care 2006;29(6):1288-93.

37. Lavery LA, Armstrong DG, Peters EJ, Lipsky BA. Probe-tobone test for diagnosing diabetic foot osteomyelitis: reliable or relic? Diabetes Care 2007;30(2):270-4.

38. Tascini C, Piaggesi A, Tagliaferri E, lacopi E, Fondelli S, Tedeschi A, Rizzo L, Leonildi A, Menichetti F. Microbiology at first visit of moderate-to-severe diabetic foot infection with antimicrobial activity and a survey of quinolone monotherapy. Diabetes Res Clin Pract 2011;94(1):133-9. CrossRef

39. Citron DM, Goldstein EJ, Merriam CV, Lipsky BA, Abramson MA. Bacteriology of moderate-to-severe diabetic foot infections and in vitro activity of antimicrobial agents. J Clin Microbiol 2007;45(9):2819-28.

40. Schaper NC, Andros G, Apelqvist J, Bakker K, Lammer J, Lepantalo M, Mills JL, Reekers J, Shearman CP, Zierler RE, Hinchliffe RJ. Diagnosis and treatment of peripheral arterial disease in diabetic patients with a foot ulcer. A progress report of the International Working Group on the Diabetic Foot. Diabetes Metab Res Rev 2012;28 Suppl 1:218-24. CrossRef

41. Most RS, Sinnock P. The epidemiology of lower extremity amputations in diabetic individuals. Diabetes Care 1983;6(1):87-91. 
42. Pecoraro RE, Reiber GE, Burgess EM. Pathways to diabetic limb amputation. Basis for prevention. Diabetes Care 1990;13(5):513-21.

43. Sohn MW, Stuck RM, Pinzur M, Lee TA, Budiman-Mak E. Lower-extremity amputation risk after charcot arthropathy and diabetic foot ulcer. Diabetes Care 2010;33(1):98-100. CrossRef

44. Hinchliffe RJ, Andros G, Apelqvist J, Bakker K, Friederichs S, Lammer J, Lepantalo M, Mills JL, Reekers J, Shearman CP, Valk G, Zierler RE, Schaper NC. A systematic review of the effectiveness of revascularization of the ulcerated foot in patients with diabetes and peripheral arterial disease. Diabetes Metab Res Rev 2012;28 Suppl 1:179-217. CrossRef
45. Gill AL, Bell CN. Hyperbaric oxygen: its uses, mechanisms of action and outcomes. QJM 2004;97(7):385-95.

46. Snyder RJ, Kisner RS, Warriner RA III, Lavery LA, Hanft JR, Sheehan $P$. Consensus recommendations on advancing the standard of care for treating neuropathic foot ulcers in patients with diabetes. Ostomy Wound Manage 2010;56(4 Suppl):S1-24.

47. Rodriguez PG, Felix FN, Woodley DT, Shim EK. The role of oxygen in wound healing: a review of the literature. Dermatol Surg 2008;34(9):1159-69. CrossRef

48. Boulton AJ, Kirsner RS, Vileikyte L. Clinical practice. Neuropathic diabetic foot ulcers. $N$ Engl J Med 2004;351(1)48-55. 